\title{
FACTORS OF SUCCESS AND MOTIVATION OF RURAL ENTREPRENEURSHIP IN EASTERN SERBIA
}

\author{
Milovan Vuković ${ }^{1}$, Igor Prvulović ${ }^{2}$, Snežana Urošević3 \\ *Corresponding authorE-mail: snezana@gmail.com
}

A R T I C L E I N F O
Review Article
Received: 06 May 2018
Accepted: 16 June 2018
doi:10.5937/ekoPolj1803085V
UDC 911.373+005.961(497.11-12)

Keywords:

Entrepreneurship, rural areas, success, motivation, Eastern Serbia.

JEL: O15, O18, L26

\section{A B S T R A C T}

This study examines success factors and motivation of entrepreneurs in the rural areas of the Eastern Serbia. The survey of the eighty entrepreneurs in the two municipalities has been conducted on the Zaječar district territory, and it included 14 villages. The weak economy, the depopulation process and the lack of financial sources are identified as problems, while the hard work and the quality of the products (services) are crucial success factors. On the other hand, political involvement had the lowest significance as the success factor. The results also indicate that the strongest motivators of the researched entrepreneurs were to be one's own boss and to increase one's own income.

(C) 2018 EA. All rights reserved.

\section{Introduction}

There have been significant changes (in particular, the demography ones) on the territory of the Republic of Serbia during the recent decades (Cvijanović, 2012). These changes have been noticed in regard to the movement of the people from the rural areas to the big towns in the search for work and better life conditions, when we compare the current tendency to the earlier one during the previous decade. There has been put an end to the migratory processes, or has, at least, been made slower the movement of the people who live in the rural areas into towns and cities. In spite of the fact that there has been a lot of research work on the different aspects of entrepreneurship in Serbia (Vukmirović, 2005; Sajfert et al., 2008; Bobera et al., 2014; Bobera et al., 2015; Leković \& Marić, 2016), the success factors and motivation that are necessary for the entrepreneurship development in the rural regions and the border regions, have not been sufficiently investigated.

1 Milovan Vuković, Ph.D., Full Professor, University of Belgrade, Technical Faculty in Bor, Vojske Jugoslavije 12, Bor, Serbia, Phone:+3816435224705 E-mail: mvukovic@tfbor. bg.ac.rs ORCID ID https://orcid.org/0000-0003-1715-1078

2 Igor Prvulović, Mr, Central-H, Čekić bb, Debeli Lug, Majdanpek, Serbia, E-mail: igor. prvulovic@gmail.com ORCID ID https://orcid.org/0000-0003-1473-0824

3 Snežana Urošević, Ph.D., Full Professor, University of Belgrade, Technical Faculty in Bor, Vojske Jugoslavije 12, Bor, Serbia, Phone: +381607150305, E-mail: surosevic@tfbor. bg.ac.rs, snezanaur@gmail.com ORCID ID http://orcid.org/0000-0002-6647-0449 
Entrepreneurship represents a significant element of the economic development (Schumpeter, 1935). It can be defined as "a proactive and innovative economic activity carried out by an individual or a group of individuals connected by a binding contract" (Maksimović et al., 2016, p. 29). The European Union (EU) gives a strong support to the idea of the rural entrepreneurship and, consequently, provides sustainability of the rural development. The entrepreneurship has thus become the focus of the interest of the authors who do the research on the different phenomena that have related to the rural areas.

Labrianidis (2016) has perceived the entrepreneurship as a means for overcoming the barriers of the development of the rural and peripheral districts in Europe, and, especially, in the conditions of the lengthy economy crisis (Leković \& Marić, 2016). Labrianidis has also pointed out what have been the three ways that could help to comprehend the aspects of the rural areas. First of all, the rural area has presented the space community that has relies on the definite economy activites (for example, agriculture and forestry) or it may be the fixed open space (for example, the mountain area). Secondary, one could define the rural area by the numerous social and spatial features; for example, the population density and how distant from the town or the city the rural area is. Finally, the meaning of the term 'rural' currently often means the social portrait of the reality in the sense of inventing the ideal share of the social organisation on the rural territory. We obviously cannot lead the term 'rural' down to only agriculture and the use of the nature sources but to the development of the different economic fields. The focus of the discussion of the research of the rural territory should, consequently, be given to the social context and the spatial context. Both of these facors have had an impact on the type and the results of the entrepreneurship activities that relate to the different fields. In a word, there is a need of establishing the relation between the entrepreneurship and the space.

The entrepreneurship success factors have usually been studied and discussed with the use of three variables, such as: (1) the external milieu influence (for example, the level of the industry development); (2) the manager's abilities and training (for example, the bussiness plan creation); and (3) the psychological and personal qualities of the entrepreneurs. Among the entrepreneurship success factors, that have been most frequently investigated, the following ones should be mentioned: the manager's abilities, the manager's education, the manager's or the entrepreneur's previous experience and training, the manager's or the entrepreneurs' psyhology features and qualities, the net of social contacts and the milieu conditions (Benzing et al., 2009). On the other hand, there has been no general agreement about what people have in mind when they describe 'success' of any entrepreneurial project. Nevertheless, the duration of the entrepreneur's work has been considered the most important criterion for the success estimation (Rogoff et al., 2004).

The main theme in the entrepreneurship field has related to the factors of motivation that make people do the entrepreneur's job. It has been thought that the motivation link between the intention and the work of the entrepreneur (Carsrud \& Brannback, 2011). Motives, in fact, reveal 'basic reasons for somebody being ready to change and orient his/her attitudes, intentions and activities what is, in any case, valid with entrepreneurs' 
(Bobera et al., 2015). Thus, it has been no surprise that a big number of the done empiric research and the motivation models that have been realized and that have related to the entrepreneurship activities both in the countries in the world (Robichaud et al., 2001; McMullin et al., 2008) and in Serbia (Živković et al., 2009; Stefanović et al., 2010).

Entrepreneurial motivations can by classified into four distinct categories: extrinsic rewards, independence/autonomy, intrinsic rewards and family security (Kuratko et al., 1997). These factors determine the motivation level of entrpreneurs which, in turn, affects their business success (Stefanović et al., 2010). Yalcin and Kapu (2008) also suggested four categories of motives: financial, recognition, freedom and family tradition - the willingness to continue family bussines and to imitate family members. These authors further differentiated among the so-called 'push' and 'pull' factors. The former relates to 'the need to increase family income, dissatisfaction with a salarybased job, problem with finding an appropriate job and the need for flexibility for family responsibilities', and the latter includes the need for independence, self/actuelization, increased status quo and reputation in society (Yalcin \& Kapu, 2008).

Two basic kinds of entrepreneurs, depending on what is the motive for starting the entrepreneurial project (necessity and opportunity), is possible to recognize (Bobera et al., 2015). While necessity entrepreneurs start the entrepreneurial projects for necessity, opportunity entrepreneurs tend to profitably use noticed chances. It is clear that the necessity enterpreneurs possess less human and financial capital.

The impact of the relevant factors upon the entrepreneurship in the rural areas will be empirically explored within this work. The above presented research question will be studied in the Zaječar border district. This administrative region is made up of the three municipalities (Boljevac, Sokobanja and Knjaževac) as well as the town of Zaječar. The Zaječar District counts 118,295 residents (according to the 2011 Census), covering the area $3,623 \mathrm{~km}^{2}$. The depopulation process has started when the number of people has reduced for 19,266 (or 14\%), compared to the 2002 Census, when 137,561 residents have lived on the teritory of this district. The city of Zaječar has had the lowest depopulation $(-11.3 \%)$, whereas the higest depopulation has experienced Boljevac $(-18.8 \%)$. The average population density on this territory is only 33 residents per $\mathrm{km}^{2}$ and it is far lesser that the average population density in Serbia.

\section{Methodology of the Research}

The applied questionnaire in this empirical research represents a slight modification of a highly used questionnaire developed by Chu and Katsioloudes (2001). These authors' questionnaire has been used in the numerous the researches of the phenomena in diferent countries; for example, in Romania, Hungary, Turkey, Ghana and Kenya (Benzing et al., 2005; Benzing et al., 2009; Chu et al., 2007). The first-made questionnaire has been adapted in order to take into account the specific nature of the context that has been chosen for doing the research. For instance, the possibilities for the entrepreneurship development in the rural areas are highly dependent on the development of the companies 
and the road network. Consequently, the statements addressing these issues have also included in the questionnaire that has been used for the purpose of conducting a survey oin the fourteen chosen willages.

The prepared questionnaire consists of four parts. The first part of this questionnaire has related to the social-demographic characteristics (gender, age, education and employment status) of the people who have participated in the survey. The second part of the questionnaire is designed in order to obtain the data about a company or a shop such as: the factory setting, the time period during which the firm has worked, the number of people who work in the firm, and the type of the activity that the factory does. The third part of the questionnaire has contained a set of statements dealing with the assessment of the different sucess factors in entrepreneurship activities (both the ones with the internal character and the ones with the external character). In order to rate the opinions of the respondents who have taken part in this survey, the answers to the questions in the questionnaire were offered according to the Lickert's scale. Consequently, the modalities of the answers have expressed the next meanings: 1 - I do not agree at all, 2 - I do not agree, 3 - I am not sure, 4 - I agree, and 5 - I absolutely agree. At last, the fourth part of the questionnare has contained a list of statements relating to the reasons that could be the motives for being an entrepreneur and the process for starting the entrepreneurship activities in the village. Ninety entrepreneurs have participated in this survey, and eighty-five questionnaires, or 94,44\%, were correct.

\section{Results and Discussion}

Descriptive statistics belongs to the group of the statistics methods that includes the processes of gathering, calculating, indicating and describing the basic features of the statistics series. Firstly, the data about respondents are given (Table 1). The upper part of this table presents the data dealing with socio-demographic characteristics of chosen respondents. The next part of this table indicates the data that relate to the time period of doing the activity as well as the kind of activities that the entrepreneurs who have participated in answering the statements in the questionnaire do.

Table 1. Data about the respondents who have participated in the survey

\begin{tabular}{|l|l|c|c|}
\hline \multirow{4}{*}{ Gender } & Categories & Number & Percent \\
\hline \multirow{5}{*}{ The years od age } & Male & 59 & 69.41 \\
\cline { 2 - 4 } & Female & 26 & 30.59 \\
\hline & Up 20 years & 0 & 0.00 \\
\cline { 2 - 4 } & From 21 up 30 years & 2 & 2.35 \\
\cline { 2 - 4 } & From 31 up 45 years & 45 & 52.94 \\
\cline { 2 - 4 } & Od 46 do 60 years & 36 & 42.35 \\
\cline { 2 - 4 } & 61 years and more & 2 & 2.35 \\
\hline \multirow{5}{*}{ Education } & Without any school & 0 & 0.00 \\
\cline { 2 - 4 } & Primary & 0 & 0.00 \\
\cline { 2 - 4 } & Secondary school & 73 & 85.88 \\
\cline { 2 - 4 } & College & 8 & 9.41 \\
\cline { 2 - 4 } & Bachelor of Art & 4 & 4.71 \\
\hline
\end{tabular}




\begin{tabular}{|l|l|c|c|}
\hline & Categories & Number & Percent \\
\hline \multirow{3}{*}{$\begin{array}{l}\text { The period of time that the } \\
\text { company (the firm) has } \\
\text { worked }\end{array}$} & Up 10 years & 34 & 40.00 \\
\cline { 2 - 4 } & From 11 up 20 years & 44 & 51.76 \\
\cline { 2 - 4 } & Over 20 years & 7 & 8.24 \\
\hline \multirow{4}{*}{$\begin{array}{l}\text { The activity (work) that } \\
\text { the company does }\end{array}$} & Trade & 54 & 63.53 \\
\cline { 2 - 4 } & Hotel and restorants Management & 19 & 22.35 \\
\cline { 2 - 4 } & Handicrafts as the production activity & 7 & 8.24 \\
\cline { 2 - 4 } & Handicrafts as the, serving activity & 5 & 5.88 \\
\cline { 2 - 4 } & Traffic & 0 & 0.00 \\
\hline
\end{tabular}

Source: Authors' calculastions

The presented data show that more men that women-fifty-nine men, or $69.41 \%$, have taken part in the survey (Table 1). The vast majority of respondents are those of the age between 31 and 45 years (forty-five of them, or 52.91\%); then come those between 46 and 60 years old 36 respondents, or $42.35 \%$ ). In terms of educational level of the surveyed entreprenuers, the largest share has consisted of those who have completed the secondary school; 73 respondents $(85.88 \%)$. More than half of them $(51.76 \%)$ has done the entrepreneurship job beetwen 11 and 20 years.

The surveyed entreprenuers were mostly (54 or $63.53 \%$ ) involved in the trade jobs make up $63.53 \%$. During the field research no activity could be recognized as an effort to develop some aspects of tourism in the contryside. This might be a worrying observation having in mind that this area is reach in the touristic attractions. On the other hand, it is not surprising that there are so many employees who do the trade job, what is in accordance with the newer research in the field of the rural economy. For example, according to the 2005 Census, the largest portion of the rural population who have a job has done the agriculture job (45\%); then, food-processing (16\%), trade $(10.2 \%), 5.8 \%$ civil engineering, 4\% transport and state administration education, health care and public welfare (3\%) (Bogdanov, 2008, 95-96).

\section{Factors of Success in Entrepreneurship}

The average values have been calculated up for every statement separately (Table 2). They have been presented in the questionnaire and they have related to the attitudes on the sucess factors in the entrepreneurship. The obtained data on the success factors were, largely, in accordance with the results presented in the similar studies, and they also involve some investigations that have been carried out in Serbia (Stefanović et al., 2010). Namely, the reliability of measurement instruments used in our study has been very high, compared to the value of Cronbach`s Alpha factor (0.750), that has been recently reported (Stefanović et al., 2011).

The average values, that have been obtained and that referred to the statements from the questionnaire, have approximately been between 3.65 and 4.84, whereas the entire average value has been 4.13. The lowest average value has been referred to the statement Q16 (the involvement into the politics), whereas the highest values have been obtained for the two 
statements: Q10 and Q11, the hard work as a success factor in the entrepreneurship and quality of the good service, respectively. Within this section, attention will be paid to the statements Q3, Q5, Q10 and Q16.

Table 2. Descriptive statististics of data

\begin{tabular}{|c|c|}
\hline Statement & $\begin{array}{l}\text { Mean } \\
\text { Value }\end{array}$ \\
\hline $\begin{array}{l}\text { The bigger and closer to the town or the city the village, the greater the (chances) } \\
\text { possibilities for the success in the small business firms (Q1). }\end{array}$ & 4.22 \\
\hline $\begin{array}{l}\text { The work of the big company in the village is suitable for the development of the small } \\
\text { family firms (Q2). }\end{array}$ & 3.72 \\
\hline $\begin{array}{l}\text { The adequate measures that the state could introduce, could improve the entrepreneurship } \\
\text { in the village district (Q3). }\end{array}$ & 3.84 \\
\hline $\begin{array}{l}\text { The training programmes that relate to the way we could start and lead the business in the } \\
\text { village would be usefull (Q4). }\end{array}$ & 3.96 \\
\hline $\begin{array}{l}\text { Having the approach to the funds has a big importance for the entrepreneur who lives in } \\
\text { the rural area (Q5). }\end{array}$ & 3.71 \\
\hline $\begin{array}{l}\text { The success achievement of somebody doing the small business is greatly dependent } \\
\text { upon the previous experience of the entrepreneur (Q6). }\end{array}$ & 4.09 \\
\hline $\begin{array}{l}\text { The family support and the friend's support is specially valuable for the work of the } \\
\text { entrepreneur who lives in the village (Q7). }\end{array}$ & 4.38 \\
\hline $\begin{array}{l}\text { The introduction of other people to one's own work has an impact on the small business } \\
\text { (Q8). }\end{array}$ & 4.09 \\
\hline $\begin{array}{l}\text { The entrepreneurs as the owners of the firms in the rural areas should also insist on the } \\
\text { quality of a product or the services that have the appropriate price (Q9). }\end{array}$ & 4.14 \\
\hline A good service is very important for the business success $(\mathrm{Q} 10)$ & 4.69 \\
\hline $\begin{array}{l}\text { Hard work is the necessary condition for the success in the field of entrepreneurship, } \\
\text { especially in the village (Q11). }\end{array}$ & 4.84 \\
\hline $\begin{array}{l}\text { If the village is nearby the highway it has a suitable impact on the work of the small } \\
\text { entrepreneurs who live in the rural areas (Q12). }\end{array}$ & 4.49 \\
\hline The good manners of handling the business books leads to the success of a firm (Q13). & 4.11 \\
\hline $\begin{array}{l}\text { A good entrepreneur should know how to play, organize and control the work of the } \\
\text { employees (Q14). }\end{array}$ & 4.24 \\
\hline $\begin{array}{l}\text { The entrepreneur's good social contacts are more than useful when we talk about the rural } \\
\text { district (Q15). }\end{array}$ & 3.94 \\
\hline $\begin{array}{l}\text { The entrepreneur's involvement into the work of politics parties could make easier the } \\
\text { way to the bussiness success (Q16). }\end{array}$ & 3.65 \\
\hline $\begin{array}{l}\text { The more intensively developed agriculture in the villages would have a beneficial effect } \\
\text { on the conditions that could enable the entrepreneurship development in rural area (Q17). }\end{array}$ & 4.08 \\
\hline
\end{tabular}

\section{Source: Authors' calculations}

In terms of the statement Q3, The adequate measures that the state could introduce could improve the entrepreneurship in the village, one can say that $75.29 \%$ respondents have agreed with this statement, $18.82 \%$ respondents have not been quite sure about the claim, and only $1.18 \%$ has not agreed with the statement that says the suitable measures that the state could introduce, could induce the entrepreneurship development in the villages. In 
spite of the fact that the success factors have been approximately assessed in many developing states, certain differences (besides the influences of economy and culture) could be attributed to the impacts of politics. The state impact upon the entrepreneurship development might, for example, be threefold: the productive impact, the non-productive impact and the destructive one (Minniti et al., 2008).

With the statement Q5, Having the approach to the funds has a big importance for the entrepreneur who lives in the rural area, three fifths of the respondents $(60.00 \%)$ have agreed, $7.06 \%$ of them have absolutely agreed with the statement, $29.41 \%$ has not been sure about it, whereas $3.53 \%$ have not agreed with this claim. In this case, the average value equals 3.71, what is somewhat lower value than those obtained in recently conducted similar studies that has been done in Serbia and other countries of the Western Balkans. This result is partly likely to be ascribed to the specific economy conditions that exist in the countryside, relating to the involvement of more than one generation into the bussiness the process of combining the different salary sourcess (both the agriculture salary sources and the non-agriculture salary sources).

The Zaječar district, for instance, along with Braničevo (25.56\%) and Bor (17\%) districts, has had a high participation of emigrants in the population, and, therefore, households in this part of Eastern Serbia receive a significant share of the remittances abroad. Yet, the high share of remittances in the average income does not necessarily mean that remittances substantially contribute to the entrepreneurial development. On the other hand, Petković (2017) has recently indicated that in Eastern Serbia the inflow of remittances has reduced only the poverty index.

The statement Q10, A good service is very important for the business success, has been absolutely supported by exactly $69.41 \%$ people whereas $30.59 \%$ people have agreed with this statement. What is worth mentioning is the fact that the factor Q10 is the second factor according to the importance it has for the entrepreneurship success (the mean value is 4.69). The good service quality, or the good product quality, has had the highest value in similarly conducted research; let us say, 4.85 (Stefanović et al., 2011). The above claim can be regarded as a good indicator for the presence of the entrepreneur's spirit in the rural milieu.

The statement Q16, The involvement into the work of the politics parties could make easier the road to the business, absolutely supports a slightly more than one-third of the respondents $(34.12 \%)$. Some respondents $(10.59 \%)$ have agreed with the statement, the other portion of the sample (45.81\%) has not been sure about the the truth of the statement. At last, some respondents $(9.41 \%)$ have not agreed with the statement that the involvement into the work of the politics parties could make easier the way to the the bussiness success.

These results, in regard to the statement Q16, have been in accordance with the previous research on the success factors in Serbia. As it has earlier been presented (Table 2), the very factor of the entrepreneurial success in the rural district has been valued the lowest value (3.65), and this fact has been in accordance with the results that have once been obtained using 79 both small and big firms. Then, the variable that has said 'the participation in the politics life', having been one of the analyzed factors of the bussiness success that has 
been graded the lowest value (1.94) (Stefanović et al., 2011). What has been interesting here, it has been the fact that the success factors have been graded by the people who have answered the questions in the questionnare the lowest value, in spite of the well-know fact that there has been a very serious link between the involvement into the politics life and the bussiness world in Serbia, as well as in the other states that have been going through the process of the economics transition.

Finally, with the statement Q17, The more intesively developed agriculture production in the villages would have a more suitable impact upon the development conditions, $11.76 \%$ respondents, who have participated in the study, have absolutely agreed with the statement, whereas $85.88 \%$ of them have agreed.

\section{Motivations in Entrepreneurship}

The fourth group of questions has related to the reasons that could enable start the business in the village areas. The answers of the respondents who have participated in the survey have been shown (Table 3 ). As it can be seen, only $2.35 \%$ respondents has declared that they would live to build up the business that could inherit their descendents, $35.30 \%$ of them has said that they would like to ensure the safe jobs for their family members, and the majority $(62.35 \%)$ has said that they would like to start and to continue a safe job for themselves.

The results that have been presented in the chart 6 are also in accordance with the similar research results. That is 'to ensure the safe business', that is the most important motif for 53 people when compared to the opinion of 85 respondents, who have participated in answering the questions in the questionnaire, has been seen as a very serious motiv in the study that has been done as well (Stefanović et al., 2010). The factor has been given the average value 4.56, that is slightly lesser that the value 'for making profit', which is 4.63 and the value 'the abilities that relate to the use of the previous experience and education' that is 4.58 (Stefanović et. al., 2010).

However, whereas the motifs 'to ensure the job for the family members' and 'the family closeness', that have been mentioned in the project, have been valued as the motives with the values 3.18 and 3.39, respectively, the results that we have obtained in this study show that the motif for starting the business has been given a very high, second place. The obtained data that have been gathered should certainly be looked at from the point of view of the respondent's effort who do the jobs in the field that the migratory processes from the village to the town should be slowed down. Also, the economy instability has forced the entrepreneurs to start taking care of themselves as well as their family members. 
Table 3. The reasons for starting business in chosen villages

\begin{tabular}{|l|c|c|c|}
\hline \multicolumn{1}{|c|}{ Value } & Frequency & Percentage & $\begin{array}{c}\text { The cumulative } \\
\text { percentage }\end{array}$ \\
\hline a. To achieve earning a high salary & 0 & 0.00 & \\
b. To start and continue the safe job & 53 & 62.35 & 0.00 \\
c. The ensure the jobs for the family members & 30 & 35.30 & 62.35 \\
d. To create the ability to realise the personal & 0 & 0.00 & 97.65 \\
$\quad$ abilities and experience & 0 & 0.00 & 97.65 \\
e. To be my own boss & 2 & 2.35 & 97.65 \\
f. To start the business that (I could pass on & & & 100.00 \\
$\quad$ descendents) my descendents could inherit & 0 & 0.00 & 100.00 \\
g. To have my own personal freedom & & 0.00 & 100.00 \\
h. To create with the help of my business the & & & \\
$\quad$ conditions that could enable my & & 100.00 & \\
$\quad$ descendents stay on the household & 85 & & \\
\hline
\end{tabular}

\section{Source: Authors's calculations}

The motif for starting the safe business, as well as the opening of the work places for the family members, is dependent upon the cultural features. The results of the new research of the motifs that relate to the starting up the business have shown that the family factors have been highly visible; for example, in Turkey (Ozsay et al., 2001). On the other hand, the job safety has proved out to be the most important motif for the starting of the business in Romania (Benzing et al., 2005).

\section{The Specifics of the Entrepreneurship in Rural Settlements}

It has also been done the research wheather the entrepreneur's spirit has been more visible when we have in mind both the number of the employees and the differences. For example, if there are firms with a bigger number of employees in the villages (for example, The Agricultural Company in Salaš, or The Transformers Production Company in the nearby village of Zvezdan), that have been present in the entrepreneur's life in the area, this can have the influence on the difference in the entrepreneurship development as well as the gender diference among the employees in the village. The review of the companies in chosen villages is given (Tables 4 and 5).

Table 4. Companies working in chosen villages on the Zaječar City area

\begin{tabular}{|c|c|c|c|c|}
\hline Place & $\begin{array}{c}\text { The complete } \\
\text { number of } \\
\text { companies }\end{array}$ & Men & Women & $\begin{array}{c}\text { The complete } \\
\text { number of } \\
\text { employees }\end{array}$ \\
\hline Grljan & 9 & 17 & 9 & 26 \\
\hline Veliki Izvor & 16 & 12 & 12 & 24 \\
\hline Rgotina & 10 & 67 & 31 & 98 \\
\hline Zvezdan & 10 & 175 & 29 & 204 \\
\hline Vražogrnac & 8 & 8 & 9 & 17 \\
\hline Lubnica & 3 & 1 & 5 & 6 \\
\hline Salaš & 22 & 113 & 58 & 171 \\
\hline
\end{tabular}

Source: Authors 
Table 5. Companies working in chosen villages of the Knjaževac Municipality

\begin{tabular}{|c|c|c|c|c|}
\hline Place & $\begin{array}{c}\text { The complete } \\
\text { number of } \\
\text { companies }\end{array}$ & Men & Women & $\begin{array}{c}\text { The complete } \\
\text { number of } \\
\text { employees }\end{array}$ \\
\hline Minićevo & 16 & 18 & 15 & 33 \\
\hline Kalna & 8 & 6 & 10 & 16 \\
\hline Podvis & 3 & 98 & 15 & 113 \\
\hline Donja Kamenica & 3 & 2 & 1 & 3 \\
\hline Štrbac & 1 & 0 & 1 & 1 \\
\hline Berčinovac & 1 & 3 & 0 & 3 \\
\hline Repušnica & 0 & 0 & 0 & 0 \\
\hline
\end{tabular}

Source: Authors

During the analysis of the assembled data, it has been noticed that the entrepreneurship spirit in the bigger villages nearby the municipality centres has mostly been developing as the family bussiness in the field of the mixture shops and firms. Grljan is, for example, when we make the comparison among the 14 villages that the research has involved, the village with the bigger population and it is located in the very vicinity of the municipality centre. At the beginning the very shop and firm owners have been the owners of the shops and firms. The more developing the bussiness has been, the bigger the need for the opening of the new work positions. Thereby, the employers have, firstly, employed their own family members. It has been only later that the employment process involving other people who have lived in the village has thus, in due course, created the family business concerning the mixed shops villages. The smaller opportunities of finding a job in the municipality centre has had impact upon the process of staying in the villages and doing the job that could involve the entire generation of families in the village.

This field research has confirmed even the assumption: The better the traffic position of the village the better, the possibilities for the entrepreneurship development in the village are. Having this fact in mind, several villages stand out: Salaš, Rgotina and Minićevo. They are situated on the higway E771 (Romania)-Kladovo-Negotin-Zaječar-Niš. The possibilities for the entrepreneurship development are better than the possibilities in the villages that have been separated from the highways and inaccessible and impassable in the winter season months.

Acording to the data that have been presented, what can be seen is that there have been 16 companies in Minićevo, what has been twice the number than, for example, in Kalna, where there have been 8 firms. On the other hand, there have been opened only three shops in Donja Kamenica, that is a shop in Štrbac. These places, unlike Minićevo, are situated by the local road Knjaževac-Pirot via Kalna, the road that has the less travel frequency.

\section{Conclusion}

The entrepreneurship on the territory of the Zaječar district has for decades been in the shadow of the big bussiness systems, that has resulted in the dependence of the entrepreneurship development of the big companies. Their disappearance and the process 
of leaving the 'shadow' of the big firms has had as a consequence the opening of the micro companies. The small firms as well as the middle-sized firms, the basis of the entrepreneurship have made, first of all, place the micro firms. The obtained results have shown that mostly men decide to do the research projects, and when we talk about the entrepreneurs people who are between 31 od 45 years old have prevailed. The vast majority of entrepreneurs has graduated from the high school, whereas the time period that they do the job has mostly been up to 10 years, the trade being the dominant business branch. Among 17 factors of the entrepreneurship success that have been investigated, the most highly valued factors of the entrepreneurs' success have been the hard work and the good service quality, whereas the involvement into the politics life had the lowest value. Finally, on the basis of research dedicated to the reasons to start entrepreneurship it can be concluded that providing the safe, long-term job is the most important factor, and, then, ensuring the work for family members.

\section{Acknowledgements}

Prepared as a part of the project Sustainability of the Identity of Serbs and National Minorities in the Border Municipalities of Eastern and Southeastern Serbia (179013), conducted at the University of Niš - Faculty of Mechanical Engineering, and supported by the Ministry of Science and Technological Development of the Republic of Serbia. Project period: 2011-2018.

\section{Conflict of interests}

The authors declare no conflict of interest.

\section{References}

1. Benzing, C., Chu, H.M., \& Szabo, B. (2005). Hungarian and Romanian Entrepreneurs in Romania-Motivation, Problems and Differences. Journal of Glob. Business, 16, 77-87.

2. Bobera, D., Leković, B., \& Berber, N. (2014). Comparative Analysis of Entrepreneurship Barriers: Findings from Serbia and Montenegro. Engineering Economics, 25(2), 167-176.

3. Bobera, D., Marić, S., \& Leković, B. (2015). Entrepreneurship as a Consequence of External Stimuli and/or Internal Incentives. Economic Themes, 53(1), 83-101.

4. Bogdanov, N. (2008). Small Rural Households in Serbia and Rural Non-Farm Economy (2nd edition). Belgrade: United Nations Development Programme Serbia.

5. Carsrud, A., \& Brannbact, M. (2011). Entrepreneurial Motivations: What Do Wee Need to Know? Journal of Small Business Management, 49(1), 9-26.

6. Chu, H.M., \& Katsioloudes, M. (2001). Cultural Context in the VietnameseAmerican Entrpreneurial Experience. Journal of Transnational Development, 7(2), 37-46. 
7. Cvijanović, D. (2012). Kako povećati konkurentnost i suficit Republike Srbije [How to increase the competitiveness and surplus of the Republic of Serbia]. Beograd: Institut za ekonomiku poljoprivrede.

8. European Commission (1997). Agenda 2000, COM (97) 2000. Luxembourg: Office for the Official Publications of the European Community.

9. Kuratko, D., Hornsby, J., \& Naffziger, D. (1997). An Examination of Owners' Goals in Sustaining Entrepreneurship. Journal of Small Business Management, 35, 24-33.

10. Labrianidis, L. (2016). Fostering Entrepreneurship as a Means to Overcome Barriers to Development of Rural Peripheral Areas in Europe. European Planning Studies, 14 (1), 1-8.

11. Leković, B. \& Marić, S. (2016). Economic Crisis and the Nature of Entrepreneurial and Management Activities. Economic Themes, 54(1), 1-44.

12. Maksimović, G., Otović, S., Demirović, D., \& Vermezović, T. (2016). A Review Envestigating Agrarian Female Entrepreneurship in the Republic of Serbia. Economics of Agriculture, 63(1), 29-46.

13. McMullin, J., Bagby, D.R., \& Palich, L. (2008). Economic Freedom and the Motivation to Engage in Entrepreneurial Action. Entrepreneurship Theory and Practice, 32(5), 875-895.

14. Minniti, M. (2008). The Role of Government Policy on Entreprenuurial Action: Productive, Unproductive, or Destructive? Entrepreneurship Theory and Practice, 32(5), 779-790.

15. Ozsoy, O., Oksoy, D., \& Kozan, K. (2001). The Characteristics of Turkish Entrepreneurs and Their Enterprise. College of Business; Alfred University. Long Island; New York.

16. Peković, D. (2017). Effects of Remittances on Rural and Regional Poverty in the Republic of Serbia. Economic Themes, 55(1), 105-120.

17. Robichaud, Y., McGraw, E., \& Roger, A. (2001). Toward the Development of a Measurement for Entrepreneurial Motivation. Journal of Developmental Entreprenuership, 6, 189-202.

18. Roggof, E.G., Lee, M., \& Suh, D. (2004). Who Done It? Attributes by Entrepreneurs and Experts of the Factors that Cause and Impede Small Business Success. Journal of Small Business Management, 42(4), 364-376.

19. Sajfert, Z. Lazić, J., \& Janković, J.M. (2008). Struktura životnih ciljeva menadžera i preduzetnika u Srbiji [Structure of life goals of managers and entrepreneurs in Serbia], Industrija, 36(2), 33-54.

20. Schumpeter, J.A. (1934). The Theory of Economic Development. Cambridge, MA: Harvard University Press. 
21. Stefanović, I., Prokić, S., \& Ranković, Lj. (2010). Motivational and Success Factors of Entrepreneurs: The Evidence from a Developing Country. Zb. rad. Ekon. fak. Rij., 28(2), 251-269.

22. Stefanović, I., Prokić, S., \& Ranković, Lj. (2011). Success Factors of Entrepreneurs: Empirical Evidence from Serbia. Industrija, 39(2), 15-27.

23. Yalcin, S., \& Kapu, H. (2008). Entrpreneurial Dimensions in Tranzitional Economies: A Review of Relevant Literature and the case of Kyrgyzstan. Journal of Developmental Entrepreneurship, 13(2), 185-203.

24. Vukmirović, N. (2005). Modeli podrške razvoju ženskog preduzetništva [Models of support for the development of women entrepreneurship]. Industrija, 33(4), 1-18.

25. Živković, Ž., Mihajlović, I., \& Prvulović, S. (2009): Developing Motivatin Model as a Strategy for HRM in Small Enterprises Under Transitional Economy. Serbian Journal of Management, 4(1), 1-27. 